Authors: Jan Burek, Marcin Płodzień, Łukasz Żyłka

Title of article: „Wpływ sposobu chłodzenia na wysokowydajną obróbkę stopu AlZn5.5MgCu” (", The influence of the cooling method on high performance cutting of the AlZn5.5MgCu")

Mechanik, Vol. 91, No. 10 (2018): pages 883-885

DOI: https://doi.org/10.17814/mechanik.2018.10.152

\title{
The influence of the cooling method on high performance cutting of the AlZn5.5MgCu alloy
}

\author{
Wpływ sposobu chłodzenia \\ na wysokowydajną obróbkę stopu $\mathrm{AlZn5.5MgCu}$
}

\begin{abstract}
JAN BUREK
MARCIN PŁODZIEŃ ŁUKASZ ŻYŁKA *
\end{abstract}

The research of the high performance cutting of the aviation aluminum alloy was conducted. Four methods of the cooling delivery: flood, internal, on rake surface, on the relief surface, were applied. The influence of the cooling method on the cutting force components and vibration amplitude was presented. KEYWORDS: high performance cutting, cooling, aluminum, end mill

Aluminum parts with complex shapes are usually produced in small series. For complex aluminum structures, thin-walledness and a large number of closed areas of relatively high depth are characteristic. The implementation of a single aerial support structure sometimes requires removing more than $90 \%$ of the material from the semifinished product. For economic reasons, it is necessary to abandon production methods that are difficult to automate, such as work and time-consuming riveting of the wing construction elements or the fuselage of the aircraft. The production efficiency is increased by increasing the machining parameters, such as axial infeed $a_{p}$, radial $a_{e}$, cutting speed $v_{\mathrm{c}}$ and feed per tooth $f_{\mathrm{z}}[1,4-6,8]$.

For these reasons, new machining methods have emerged, such as machining with high cutting speeds HSC (high speed cutting) and high-performance machining HPC (high performance cutting). HSC machining is mainly used at the finishing stage, and its advantages include increased productivity, reduced energy impact of the tool on the workpiece and improved quality of the work surface. In contrast to the HSC treatment, the HPC method is mainly used in the roughing stage. It ensures a significant reduction of production time and costs.

However, both methods also have some practical limitations $[1,4,6,8]$. They mainly result from high values of machining parameters such as $a_{p}$, ae and $f_{z}$, and large crosssections of the cutting layer, which in turn affect the increase of the values of the cutting force components. An equally big problem is the need to quickly evacuate a significant amount of chips, which results from the difficult access of cooling-

* Dr hab. inż. Jan Burek prof. PRz (jburek@prz.edu.pl), dr inż. Marcin Płodzień (plodzien@prz.edu.pl), dr inż. Łukasz żyłka (zylka@prz.edu.pl) - Katedra Technik Wytwarzania i Automatyzacji, Wydział Budowy Maszyn i Lotnictwa Politechniki Rzeszowskiej lubricating liquid (coolant) to the cutting zone. As a result, too high cutting forces may cause plastic deformation of the machined walls already at the stage of roughing, which in the case of load-bearing structures of aircraft may be the reason for the machining faults. On the other hand, the inadequate supply of coolant to the cutting zone can contribute to the increase of the adhesive effect and impede chip evacuation from the cutting zone and promotes filling up the flute.

That is why it is so important to control the milling in terms of cutting force, size and form of the chip and its evacuation $[1,4-6]$. It is necessary to properly prepare the cutting tool for high-speed milling in terms of macro-geometry and the method of coolant delivery. As research has shown, the selection of the geometry of the cutting edge shape and the helix angle of the cutting edge significantly affect the values of the components of the cutting force as well as the size and form of chips [1-3, 7]. Also the coolant feeding method alone has a significant effect on the dynamic processes in the cutting zone. This mainly concerns the impact of these forces on tool vibrations.

The aim of this research was to determine the effect of the method of coolant feeding to the cutting zone on the values of the cutting force components as well as the value of the vibration amplitude induced by hydrodynamic forces originating from coolant streams.

\section{Test conditions}

High performance milling trials were carried out on DMG100 monoBlock DMG machining center (fig. 1). The measurements of the cutting force components were recorded using a measuring platform with an original design, consisting of four single-piece Kistler piezoelectric dynamometers type 9601A31. Measurement of the vibration amplitude was performed using a three-piece vibration sensor PCB 356B21. Solid carbide end mills with diameter $d$ $=20 \mathrm{~mm}$ and helix angle of the cutting edge $\lambda=30^{\circ}$ and a variable delivery method of coolant were used.

The research was carried out using four coolant supply methods: flooding, central cooling (with holes: $\varnothing 3 \mathrm{~mm}, \varnothing 4$ $\mathrm{mm}, \varnothing 5 \mathrm{~mm}$ ), on the relief surface and on the rake surface (fig. 2). 


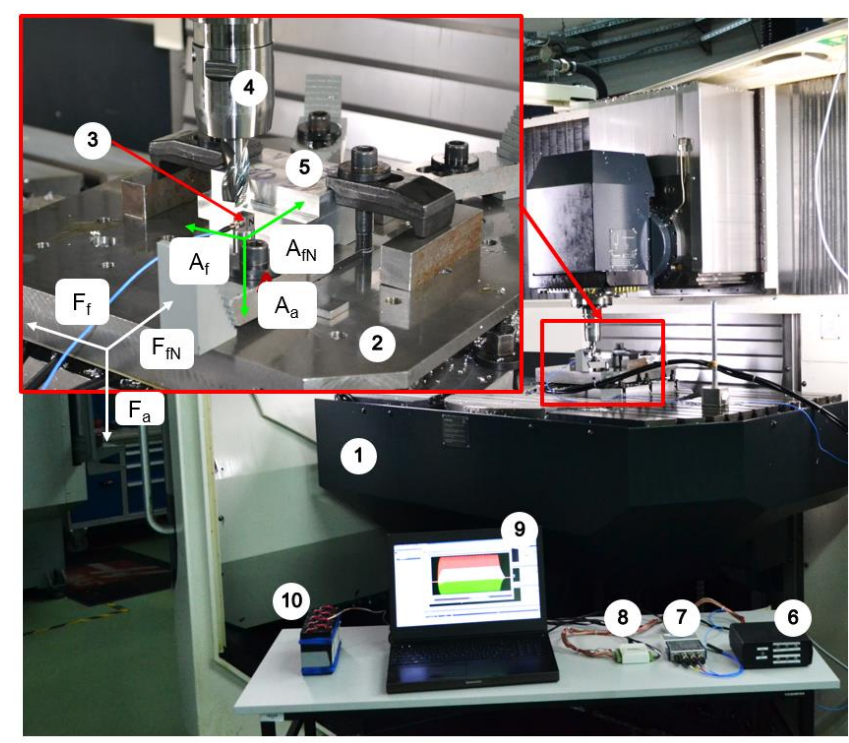

Fig. 1. Test stand: 1 - Milling center DMU100 monoBlock, 2 - platform for the components of the cutting force, 3 - vibration amplitude sensor, 4 - test cutter, 5 - test sample, 6 - load amplifier, 7 - A/C converter vibration sensor, $8-\mathrm{A} / \mathrm{C}$ converter for cutting force, 9 computer with software, 10 - external power source for the measuring platform

a)
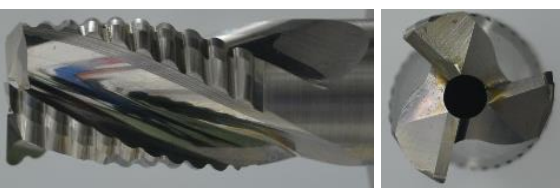

b)
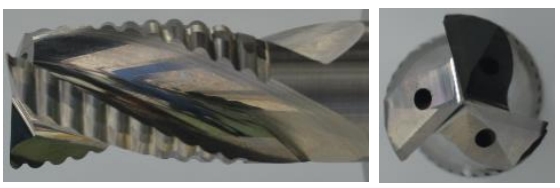

c)
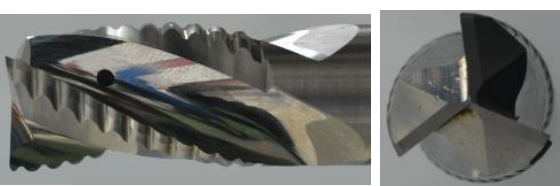

Fig. 2. Methods of CCS feeding: a) central, b) to the relief surface, c) on the rake face

The samples were made of $\mathrm{AlZn5.5MgCu}$ aluminum alloy (7075). Constant machining parameters were adopted: cutting speed $v_{\mathrm{c}}=694 \mathrm{~m} / \mathrm{min}$, axial infeed $a_{p}=15 \mathrm{~mm}$ and volume capacity $Q_{w}=594 \mathrm{~cm}^{3} / \mathrm{min}$. The constant volumetric productivity was obtained by selecting pairs of technological parameters: radial infeed $a_{\mathrm{e}}=8 ; 12 ; 16 \mathrm{~mm}$ and feed per tooth $f_{z}=0.15 ; 0.10 ; 0.075 \mathrm{~mm} / \mathrm{z}$.

\section{Results}

Fig. 3 shows the relative change in the components of the cutting force (feed $F_{\mathrm{f}}$, normal to feed $F_{\mathrm{fN}}$, axial $F_{\mathrm{a}}$ ) for different methods of coolant feeding in comparison with the flooding method (conventional).

From the analysis of the values of the cutting force components for the parameters $a_{e}=8 \mathrm{~mm}$ and $f_{z}=0.15$ $\mathrm{mm} / \mathrm{z}$, it follows that the feed component $F_{\mathrm{f}}$ and axial $F_{\mathrm{a}}$ decrease on average by approx. $4 \%$ regardless of the method of coolant feeding. The largest reduction of the feed component $F_{\mathrm{f}}$ was obtained for the central way with a hole $\varnothing 5$ $\mathrm{mm}$, while the axial component $F_{\mathrm{a}}$ - for the central way with a hole $\varnothing 3 \mathrm{~mm}$. The relative changes in these force components were $5.5 \%$ and $7.5 \%$, respectively.
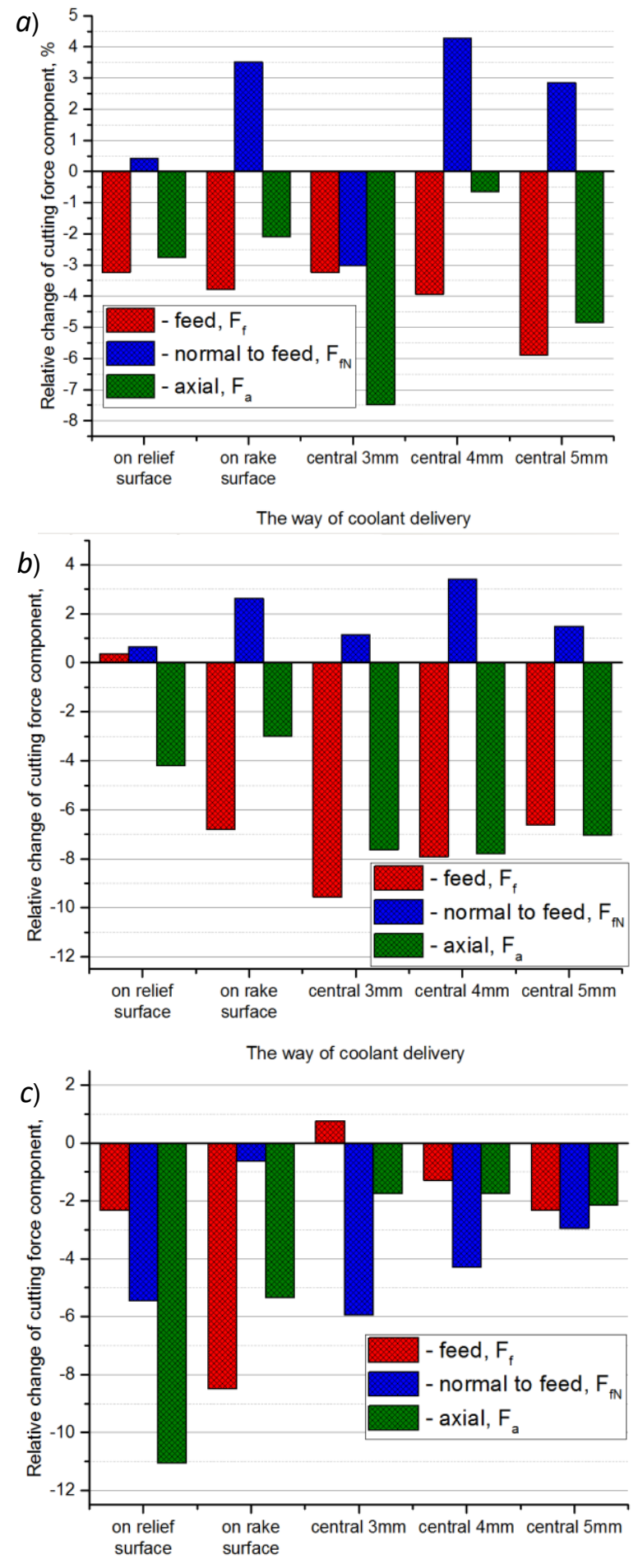

The way of coolant delivery

Fig. 3. Relative change in the cutting force components for different coolant delivery methods in relation to the flooding method; parameters: a) $a_{\mathrm{e}}=8 \mathrm{~mm} ; f_{\mathrm{z}}=0.15 \mathrm{~mm} / \mathrm{z}$, b) $a_{\mathrm{e}}=12 \mathrm{~mm} ; f_{\mathrm{z}}=0.10$ $\mathrm{mm} / \mathrm{z}, \mathrm{c}) a_{\mathrm{e}}=16 \mathrm{~mm} ; f_{\mathrm{z}}=0.075 \mathrm{~mm} / \mathrm{z}$

In most coolant delivery methods, a few percent increase in the normal to feed component $F_{\mathrm{fN}}$ value was obtained in relation to the flooding method. The largest increase - $4.5 \%$ was noted for the central way with a hole of $\varnothing 4 \mathrm{~mm}$ (fig. 3a).

Analysis of the relative change in the cutting force components for the technological parameters $a_{e}=12 \mathrm{~mm}$ and $f_{z}=0.1 \mathrm{~mm} / \mathrm{z}$ shows the reduction of the feed component $F_{f}$ and the axial cutting force $F_{\mathrm{a}}$ (by approx. $9.5 \%$ and $7.5 \%$ respectively). The largest drop was in these components for the central way with a hole of $\varnothing 3 \mathrm{~mm}$. A few percent increase in the normal to feed component $F_{\mathrm{fN}}$ of the cutting force was obtained. The largest increase $(3.5 \%)$ was obtained for the central way with a hole of $4 \mathrm{~mm}$ (fig. $3 \mathrm{~b}$ ). 
In the case of technological parameters $a_{\mathrm{e}}=16 \mathrm{~mm}$ and $f_{\mathrm{z}}$ $=0.075 \mathrm{~mm} / \mathrm{z}$, you can see the lowering of the cutting force components in most coolant feeding methods. The best results were obtained for the method of feeding to the relief surface - the feed component $F_{\mathrm{f}}$ decreased by $2 \%$, the normal to feed $F_{\mathrm{fN}}$ - by $5 \%$ and the axial $F_{\mathrm{a}}$ - by $11 \%$ (fig. $3 \mathrm{c}$ ).

It can be stated that the choice of the coolant delivery method influences, but only slightly, the values of the cutting force components. The reason for such significant differences in the results may be a change in the process of forming and evacuation of chips depending on the process settings, as well as the hydrodynamic impact of coolant.

Fig. 4 shows the relative change in the components of the amplitude of vibration in the feed direction $A_{\mathrm{f}}$, normal to feed $A_{f N}$ and axial $A_{a}$ for different methods of coolant feeding in comparison with the flooding method.

a)

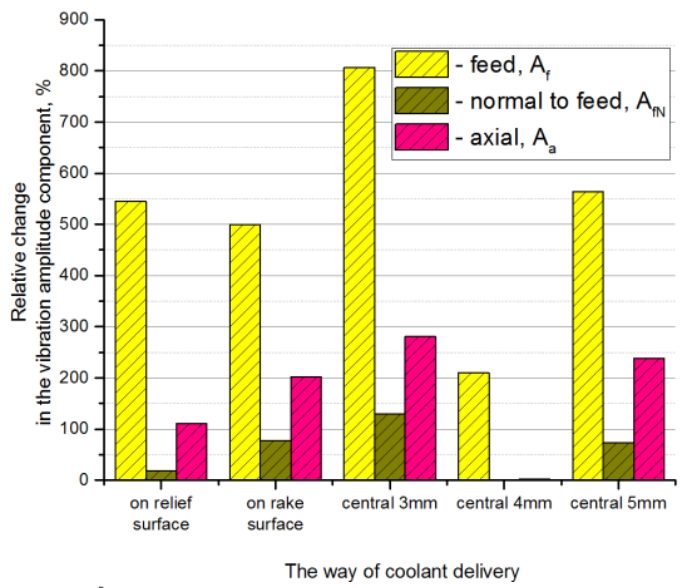

b)

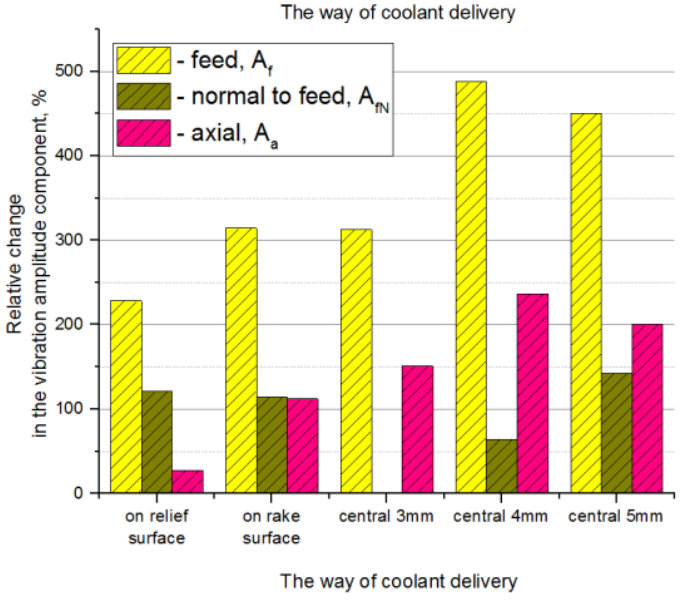

c)

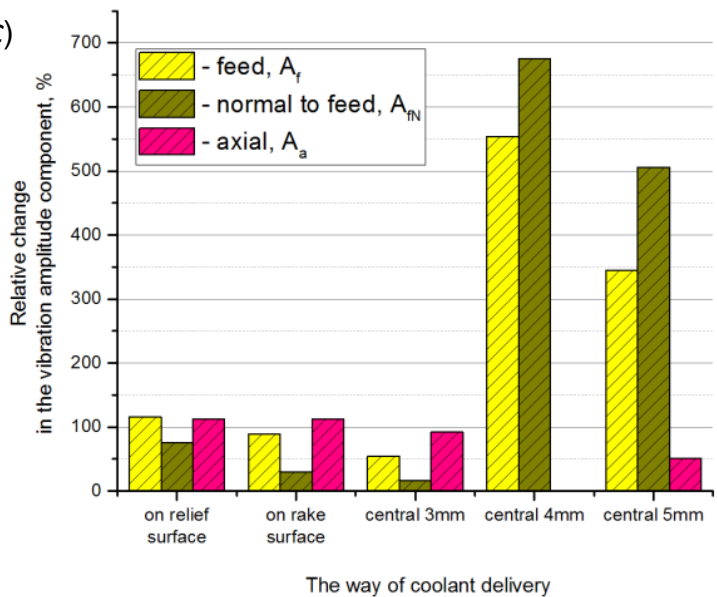

Fig. 4. Relative change of the components of the vibration amplitude for different ways of coolant delivery in relation to the flooding method; parameters: a) $\left.a_{\mathrm{e}}=8 \mathrm{~mm} ; f_{\mathrm{z}}=0.15 \mathrm{~mm} / \mathrm{z}, \mathrm{b}\right) a_{\mathrm{e}}=12 \mathrm{~mm} ; f_{\mathrm{z}}$ $=0.10 \mathrm{~mm} / \mathrm{z}, \mathrm{c}) a_{\mathrm{e}}=16 \mathrm{~mm} ; f_{\mathrm{z}}=0.075 \mathrm{~mm} / \mathrm{z}$
From the analysis of the results, shown in fig. 4 , it can be concluded that the use of different coolant delivery methods causes a significant increase in all components of the vibration acceleration amplitude compared to the flooding method. The largest increase in amplitude was noted respectively for the feed component $A_{\mathrm{f}}$, axial $A_{\mathrm{a}}$ and normal to feed $A_{\mathrm{fN}}$.

For parameters $a_{\mathrm{e}}=8 \mathrm{~mm}$ and $f_{\mathrm{z}}=0,15 \mathrm{~mm} / \mathrm{z}$ components increased in the range of $A_{\mathrm{f}}=200 \div 800 \%, A_{\mathrm{fN}}=15 \div 240 \%$, $A_{a}=50 \div 300 \%$ - depending on the method of coolant feeding. The lowest increase was obtained in the case of the central method with a hole $\varnothing 4 \mathrm{~mm}$ (fig. $4 \mathrm{a}$ ).

With the parameters $a_{\mathrm{e}}=12 \mathrm{~mm}, f_{\mathrm{z}}=0.10 \mathrm{~mm} / \mathrm{z}$, an increase in the vibration amplitude was also observed. Depending on the method of coolant delivery, the following components increase in the following ranges was observed: $A_{\mathrm{f}}=200 \div 480 \%, A_{\mathrm{fN}}=0 \div 150 \%, A_{\mathrm{a}}=30 \div 220 \%$. The smallest increase in the vibration amplitude was noted for the method of feeding to the relief surface (fig. 4b).

The lowest vibration amplitude increase was noted for the following parameters: $a_{\mathrm{e}}=16 \mathrm{~mm}$ and $f_{z}=0.075 \mathrm{~mm} / \mathrm{z}$ for most of the coolant delivery methods tested. In the case of supplying coolant on the rake and relief surfaces and the central feed with the $\varnothing 3 \mathrm{~mm}$ hole, the relative increase in vibration amplitude in the feed $A_{\mathrm{f}}$ and axial direction $A_{\mathrm{a}}$ was about $100 \%$, while the normal to feed component $A_{\mathrm{fN}}$ increased by $80 \%$ (fig. 4c).

The increase in vibration amplitude in the case of cutters with internal coolant feed can be explained by the reduction of the tool stiffness due to the presence of internal channels (change in the cross-section), as well as the hydrodynamic effect of coolant on the tool.

\section{Conclusions}

The research shows that the coolant delivery method has a minor influence on the values of the cutting force components. For the majority of methods, a decrease in the cutting force components was observed at an average of $5 \%$ compared to the flood method of coolant. On the other hand, a significant increase in the vibration amplitude has been noted for all coolant delivery methods in relation to the flooding method. Often, depending on the method of feeding (the shape of internal channels), the amplitude of vibrations increased - in some cases even by $500 \%$ compared to flood cooling.

Obtained results also indicate that it is better to use larger radial feeds $a_{e}$ than feeds per tooth $f_{z}$ (fig. 4c), while maintaining constant machining efficiency.

\section{REFERENCES}

1. Burek J., Żylka L., Płodzień M., Gdula M., Sułkowicz P. "The influence of the cutting edge shape on high performance cutting". Aircraft Engineering and Aerospace Technology. 90, 1 (2018) pp. 134-145.

2. Tehranizadeh F., Budak E. "Design of serrated end mills for improved productivity". Procedia CIRP. 58 (2017): pp. 493-498.

3. Burek J., Żylka L., Płodzień M., Buk J., Sułkowicz P. „Wpływ kąta pochylenia krawędzi skrawającej frezu na proces odprowadzania wiórów ze strefy skrawania". Mechanik. 11 (2017): pp. 962-964.

4. Kuczmaszewski J., Zaleski K. „Obróbka skrawaniem stopów aluminium i magnezu". Lublin: OWPL (2015).

5. Burek J., Płodzień M. „Wysoko wydajna obróbka części ze stopów aluminium o złożonych kształtach". Mechanik. 7 (2012): pp. 542-549.

6. Kawalec A., Oczoś K.E. „Kształtowanie metali lekkich”. Warszawa: PWN, 2012.

7. Izamshah R., Yuhazri M.Y., Hadzley M., Amran M. "Effects of end mill helix angle on accuracy for machining thin-rib aerospace component". Applied Mechanics and Materials. 315 (2013): pp. 773-778.

8. Oczoś K.E. „Obróbka wysokowydajna - HPC”. Mechanik. 11 (2004): pp. 701-709. 
Translation of scientific articles, their computer composition and publishing them on the website www.mechanik.media.pl

by original articles in Polish is a task financed from the funds

of the Ministry of Science and Higher Education designated for dissemination of science.

\section{Ministry of Science and Higher Education}

Republic of Poland 